\title{
Strength and isometric torque control in individuals with Parkinson's disease
}

\author{
Marcio Alves Oliveira • Ana Melissa Rodrigues · \\ Raphael Maciel Silva Caballero • \\ Ricardo Demetrio Souza Petersen · Jae Kun Shim
}

Published online: 6 February 2008

(c) Springer-Verlag 2008

Erratum to: Exp Brain Res (2008) 184:445-450

DOI 10.1007/s00221-007-1212-9

In the published original version of the article, the family names of the authors are not given correct. The names should read as follows:

M.A. Oliveira, A.M. Rodrigues, R.M.S. Caballero, R.D.S. Petersen, J.K. Shim

The online version of the original article can be found under doi:10.1007/s00221-007-1212-9.

M. A. Oliveira $(\bowtie) \cdot$ A. M. Rodrigues $\cdot$ J. K. Shim Department of Kinesiology, University of Maryland, 2318, College Park, MD 20742, USA

e-mail: marcio@umd.edu

A. M. Rodrigues - R. M. S. Caballero - R. D. S. Petersen

Department of Physical Education,

Federal University of Rio Grande do Sul, Porto Alegre, RS, Brazil 